\title{
Preparation Problems of Managers in Modern Conditions
}

\author{
Ugryumova Natalya Viktorovna \\ Department of Management and \\ Marketing \\ Chelyabinsk branch of Financial \\ University under the Government of the \\ Russian Federation \\ Chelyabinsk, Russia \\ unv1965@mail.ru
}

\author{
Bubin Mikhail Nikolaevich \\ Department of Management and \\ Marketing \\ Chelyabinsk branch of Financial \\ University under the Government of the \\ Russian Federation \\ Chelyabinsk, Russia \\ mikhailbubin@rambler.ru
}

\author{
Perevozova Olga Vladimirovna \\ Department of Management and \\ Marketing \\ Chelyabinsk branch of Financial \\ University under the Government of the \\ Russian Federation \\ o-v-perevozova@mail.ru
}

\begin{abstract}
Nowadays challenges of modern education have new priority orientations which require detailed review of the whole competence- and-context-based system to prepare modern specialists. Universities improve educational models, review educational systems and start using new teaching methods. Best efforts in the educational environmental are focused on the solving of the problems manager's professional competence formation. Educational system need in scientific achievements connected with development of educational paradigms.
\end{abstract}

Keywords -Challenges, modern education, competencecontext system, training of modern specialists, educational environment, educational paradigms

\section{INTRODUCTION}

New conditions of state and economic policy resulted in revisions of higher education system, wherefore there is a need in research study connected with solving of the challenges. Profound changes which take place in Economy, politics and social relations of modern society in conditions of world crisis require fundamental reforms in an education sector.

New requirements for professional preparation of the managers are caused by several factors, the most important of which are $[10,11,15]$ :

- a growing gap between job market needs and resources of educational services market;

- deep social significance of professional activities of the managers when taking professional decisions, increase of responsibility for the fall-out of inadequate professional activities;

- dynamic economic climate which provides with the conditions for the activities in different situations;

- social significance of the managers' professional activities when accepting management decisions.

So, one of the most important aspects is the formation of competitiveness when studying in the universities.

\section{RESULTS AND DISCUSSION}

In the present article we will describe the main meaning of the competence-based system meaning on basis of the previous research in respect to the formation of the managers' competitive ability.

The formation of the competence-based system of training involves the basic idea of research, general position, conceptual and categorical framework; the system of methodological approach, principle trends, and system of the principles,goals and objectives, means and methods of achieving goals, as well as subject matter. Such structure of the research elements as the system of the scientific knowledge presents it as an integral theory, provides logical flow, completeness and consistence, the integrity authors' conclusions, expressly determining the sphere of effective application.

The foregoing performs more detailed discovery of the further work supposing:

- evaluation of the background and development degree, application of formed paradigms in the professional education of the managers;

- formation of methodological approach to the system design of managers' competitive ability on the polyparadigmatic basis;

- The formation of the competence-based system of the managers' competitive ability.

The studying of the problem of high school modernization showed that the system of high education at the beginning of the 1990s entered a new phase of its functioning $[1,2,3]$. This phase means the beginning of transit from technocratic target function (training of specialists for professional needs) to humanitarian goals (arrangement of conditions for universal professional formation during educational activity).

At the level of methodological analysis the problem of education modernization as well as paradigm shift were researched by many specialists who considered that current changes lead to formation of the type of culture for which only "know - how" education is unacceptable. [4,5,6].

Traditionally the "paradigm" is accepted as science methodology idea, however, multidimensionality, inconsistency, permanent variability of the modern sociocultural environment dictate the need for alternative conceptions on the one hand, and their exact methodological explanation, on the other hand.

In educational area there is somewhat different explanation of the pedagogical paradigm-complex of theoretic, methodological and other positions accepted by the academic community at every step of pedagogic development, which are used as the sample (model, standard)when solving pedagogical problems; the distinct set of instructions.

Let's view the main educational paradigms in respect to the professional education.In the abstract of the paradigms of professional education the most valuable for our research are the proceedings of O.V. Borisova., N.T. Bunimovch., 
S.N. Tabunov., Y. O. Valitova., A.A.Verbitskiy., O.B. Ermakova., E.B. Evplova and etc.[5, 6,7,8,9].

Vocational pedagogics gives the meaning of the world paradigmas complex of theoretical and methodological factors determining case study which is realized practically thus far. Summarizing essential features of the worlds "paradigm" and "pedagogical paradigms" and projecting them in the area of professional pedagogy, as professional pedagogical paradigm we understand the complex of theoretical, methodological and practical guidelines accepted by the scientific community at this stage of the development of vocational pedagogy that are used as a sample(conceptual and practical models, standard) formulation, research and solving of pedagogical problems; a particular set of regulations.

For professional education of the manager the most important comparative characteristics of the main paradigms of learning (Table 1)[15].

TABLE 1. ClassificATION PARAMETERS OF THE PROFESSIONAL EDUCATION PARADIGMS

\begin{tabular}{|c|c|c|c|}
\hline & \multicolumn{3}{|c|}{ Paradigm (the type of training) } \\
\hline Parameter & Cognitive-oriented & Personal-activity approach & Personal-developing professional \\
\hline $\begin{array}{l}\text { The model of professional } \\
\text { activity }\end{array}$ & Adaptivebehavior & Professional growth & Dynamic professionalism \\
\hline Goalorientation & $\begin{array}{l}\text { The formation of knowledge, } \\
\text { skills, and scientific world view }\end{array}$ & $\begin{array}{l}\text { The formation of knowledge, skills, } \\
\text { and generalized ways of intellectual } \\
\text { and practical actions, abilities, } \\
\text { personality traits, and other } \\
\text { qualities that ensure the success of } \\
\text { the practical activities }\end{array}$ & $\begin{array}{l}\text { The development of metaeducation of } \\
\text { personality, actualization of vocational and } \\
\text { psychological potential, forecasting of the } \\
\text { professional growth }\end{array}$ \\
\hline $\begin{array}{l}\text { Psychologicaltheoryoflearn } \\
\text { ing }\end{array}$ & $\begin{array}{l}\text { Cognitive psychology and } \\
\text { associative reflex training } \\
\text { concept. Individual approach is } \\
\text { to adapt learning content to the } \\
\text { individual psychological } \\
\text { characteristics of the student. } \\
\text { The student is the object of } \\
\text { pedagogical impact. }\end{array}$ & $\begin{array}{l}\text { Psychological theory of activity } \\
\text { and the theory of gradual formation } \\
\text { of mental and practical actions. } \\
\text { Individual approach is to provide } \\
\text { the student with the individual, the } \\
\text { most favorable trajectories of } \\
\text { teaching, taking into account his } \\
\text { cognitive and professional abilities. } \\
\text { The studentisthe subject of } \\
\text { pedagogical influence }\end{array}$ & $\begin{array}{l}\text { The theory of developmental education - } \\
\text { the dialectic relationship between training } \\
\text { and development: training is ahead of } \\
\text { mental development, and the development } \\
\text { determines the success of learning. } \\
\text { Individual approach is the consideration of } \\
\text { capabilities of students when determining } \\
\text { the content of education. Student is the } \\
\text { subject of pedagogical influence. }\end{array}$ \\
\hline Trainingphilosophy & $\begin{array}{l}\text { Scientific character, availability, } \\
\text { regularity, } \\
\text { strength, } \\
\text { consciousness, activity, } \\
\text { presentation, linking theory with } \\
\text { practice, taking into account } \\
\text { individual and age peculiarities. }\end{array}$ & $\begin{array}{l}\text { Focus on the development of } \\
\text { activity structures, the priority of } \\
\text { didactics and methodology, a } \\
\text { combination of individual work } \\
\text { with group forms, the teachings at } \\
\text { individual pace and style and } \\
\text { adaptation of teaching methods to } \\
\text { the cognitive abilities of students, } \\
\text { providing feedback. }\end{array}$ & $\begin{array}{l}\text { The inherent value and individuality of a } \\
\text { trajectory of professional development; the } \\
\text { congruence of the content of vocational } \\
\text { education to the innovative nature of the } \\
\text { professional activity; taking into account } \\
\text { subjective experience. }\end{array}$ \\
\hline Contentofeducation & $\begin{array}{l}\text { Pedagogically adapted system of } \\
\text { knowledge, skills and abilities, } \\
\text { experience of creative activity } \\
\text { and emotional relations, the } \\
\text { digestion of which is intended to } \\
\text { ensure personal development }\end{array}$ & $\begin{array}{l}\text { Block- modular arrangement and } \\
\text { adapted to individual professional } \\
\text { characteristics of groups of } \\
\text { students. Orientation on the } \\
\text { specific type and level of activity }\end{array}$ & $\begin{array}{l}\text { General socio-economic and legal } \\
\text { knowledge. Comprehensive, technical, } \\
\text { professional and special training. Advanced } \\
\text { and innovative training. Advanced } \\
\text { professional education. The psychological } \\
\text { experience of specialists. Professional } \\
\text { duties }\end{array}$ \\
\hline Evaluationcriterion & $\begin{array}{l}\text { Level of training - the formation } \\
\text { of knowledge, skills, abilities, in } \\
\text { accordance with State } \\
\text { Educational Standard }\end{array}$ & $\begin{array}{l}\text { Level of training - the formation of } \\
\text { knowledge, skills, abilities, in } \\
\text { accordance with State Educational } \\
\text { Standard }\end{array}$ & $\begin{array}{l}\text { The level of development of basic personal } \\
\text { substructures: orientation, competence } \\
\text { (proficiency), cognitive abilities, } \\
\text { professionally important qualities, } \\
\text { psychophysiological properties }\end{array}$ \\
\hline EducationalTechnology & Traditional & Pragmatist & Enriching \\
\hline $\begin{array}{l}\text { Types of educational } \\
\text { techniques }\end{array}$ & $\begin{array}{l}\text { Explanatoryandillustrative, } \\
\text { reproductive }\end{array}$ & $\begin{array}{l}\text { Modular, problem-based, } \\
\text { computer-based learning }\end{array}$ & $\begin{array}{l}\text { The enrichment of socio-professional } \\
\text { orientation enriching psychological } \\
\text { assessment. Trainings of development. } \\
\text { Structural- pragmatist games. Project } \\
\text { method. Cognitive designing. }\end{array}$ \\
\hline
\end{tabular}

All considered paradigms of education are in demand currently. Their choice is determined by the profession and the specialty, by the content of the discipline, subjunctive experience of the teacher.
Our research confirmed the position of many modern scientists who suppose that at each step one of the paradigms of education is approved: the first phase, a cognitive-oriented, on the second (main) - activity-oriented, at the final stage - personal educational professional. 
The implementation of theparadigms in theory and practice of vocational education can be represented by a curve, reflecting the dynamics of the professional development process of personality on the stage, which depends on the conformity to actual developments of educational and professional activity of the students and regulatory activities, arranged according to the logic of development. In case of compliance there is a transformation of the structural components of personality (progressive development). Otherwise, the development curve is converted to a "plateau",asymptotically approaching to a new level, but never reaches it. We emphasize that the transition to a higher level is possible only with the development of the activities of lower level [15].

It is important to find the correct scientific approaches in which to form new and more effective paradigm of modern education. Here we high light some of the most optimal approaches - systematic and competence-based-context [15]. In this case, we agree with the scientific position of $\mathrm{L}$. V. Lvov who offers these approaches as key ones.

The system approach as a General scientific basis of the study allows to consider the phenomenon of competitiveness as a system, and the process and result of professional training of manager is considered as a pedagogical system. In particular, the object of study is considered as a system of professional education of managers, and subject of research - a systematic process of formation of competitiveness of managers on the competence and context-base. Pedagogical system of professional education of managers were studied as a multidimensional system with a selection of elements, relationships, and systemic factors. System understanding of competence as pedagogical conditions of effective formation of competitiveness has allowed to reveal its characteristics as a subsystem of the modern educational system, to reveal the attribute (intrinsic) regularities, patterns of causation, laws of efficiency.

Competence-context approach is a priority orientation for educational goals: study skills, personal identity, selfactualization, socialization and personality development by creating conditions for taking pass-through, split-level system of educational and professional competences in the process of consistent implementation of the relevant activities to ensure that the ability and readiness of graduates for professional success and socio-professional mobility [15].

Competence-context approach as a strategy of the system design on specific scientific level allowed us to explore the process of professional education of the manager at the same time in-target, substantial, operational-activity and technological aspects, and also to consider the competitiveness of the managers at the theoretical level, as the aim of developing vocational education in pedagogics. In psychology, the competitiveness can be considered as a certain level of competence, i.e. it may be considered as personal growth, requiring a specially organized process.

However, the modern theories more and more give pride of place not so much to classical approaches but to more adaptive to modern economic realities. So, at the present stage of pedagogy development is polyparadigmatic approach is of a great importance.
In the pedagogical science the polyparadigmatic approach (polyparadigm) is interpreted, first, as a research methodology; second, as a theory of conceptual modeling of the educational system; third, as a theoretical basis of the design and implementation of the learning process.

Our research has shown that polyparadigmatic approach can be successfully applied in two forms: as a theory of conceptual modelling of educational system when training manager and as a theoretical basis to design and implement the normative educational system of competitiveness formation $[11,12,13,14,15]$.

As the theory of conceptual modeling of the educational system of managers, polyparadigm means the following:

- the model of formation of competitive manager represents the form of developing professional educational system and involves simultaneous application of cognitivebased, personal-pragmatist and professionally-enriching learning styles;

- training types, as the components, are pass-through, but at each pass-through line one of the types dominates;

- the predominant type of training is determined by the future professional activities type (dominant or nondominant), the planned level of competitiveness;

- the transition to the next type of training is carried out on the basis of an objective assessment of a sudden stop in the results of the absorption of the education content components;

-control of competitiveness formation is possible when using bifurcation points. These points are the moments when learning types change;

- unstable dynamic balance of the educational process as a source of managers' competitiveness formation reflects the relationship of personality, education and profession.

As a theoretical basis of the normative educational system design and implementation, polyparadigm for each type of study provides :

- learning principles;

- content of education;

- training facilities;

- the system of criteria, indicators, levels and indicators of assessment;

- EdTech types.

Therefore, in the framework of the polyparadigm approach, the professional development model of the competence and context system of manager's competitiveness formation can be seen as a project (the result of designing) schematic representation of the structure of the pedagogical system.

Thus, we can say that the competitiveness of the graduates from the point of view of modern educational requirements should satisfy, first, the needs of the individual in education, second, the needs of the labour market and the needs of employers in the growth and development of human resources and thirdly, the needs of society in the reproduction of skilled labor and the formation of a certain personality type [1-11].

\section{CONCLUSION}

Training of the specialists who meet needs of our time competitive managers - is the most important task of vocational education, its practical orientation. Education is the main indicator of competitiveness of a graduate, 
demonstrative evidence of which are the certificates (certificates, diplomas, licenses, etc.), which characterize, firstly, the time rate of education, that is, the amount of time index of education (General and special), and secondly, the amount of professional skills and competencies. It allows to speak about thematic justification in its future prospects, as the system of education in Russia focused on the implementation of the Bologna agreement, approved the priority of the formation of the basic competencies of the individual in the process of its formation in various spheres of life. Accordingly, we can assert that one of the leading directions of education modernization is formation of competitiveness of graduates, including managers. In this regard competitiveness as the level of formation of competence and competence of managers has fundamental importance.

The specifics of the professional education process is its focus on the adaptation of a future manager to the peculiar nature of the activity in conditions of inevitable competition, to educate themselves in a specific practice area and to support the professional growth of graduates. The process of formation of competitiveness is based on close correlation of socio-economic situation and the formation of student's personality, based on the assimilation of social experience of generations as the conditions of its development. The socio-economic situation underlines the need for the trainees to gradually assimilate concepts such as "competition", "business", "leadership", "professionalism", etc. that inevitably accompany professional activities.

All this allows us to conclude that pedagogical problems of modern education at this stage of development are able to actively search for new paths and directions for the improvement of pedagogical processes.

\section{REFERENCES}

[1] M. V. Asainov Formation of managers' professional competence of socio-cultural activities in the universities of culture and arts: author. dis. kand. PED. sciences'. M., 2005. 20 p.

[2] V. I. Baydenko Identification of graduates' competences set as a necessary stage in the design of STATE VPO new generation: Method. benefit. M., 2006. $212 \mathrm{p}$.

[3] S. Borisenko. Training of competitive specialists in the field of Economics: dis... Cand. PED. sciences'. Komsomolsk-on-Amur, 2004. $219 \mathrm{~S}$

[4] N. V. Borisova. Design training in the system of competence-based education // vocational education, 2009, No. 2.

[5] O. V. BorisovaThe Competitiveness of University graduates on the labour market: methodological approaches: author. dis. kand. PED. sciences'. Omsk, 2009. 22 p

[6] N. T. Bunimovich, S. N. Herds The formation of competitiveness in the context of educational reform // Education, 2007, № 6 .

[7] Yu. O. Valitova Organizational-methodical conditions of increase of competitiveness of graduates of pedagogical universities in the direction of "Technological education". kand. PED. sciences'. SPb, 2005. $183 \mathrm{p}$.

[8] A. Verbitsky, O. B. Ermakova School contextual learning as a model of realization of competence approach in education // Pedagogika, 2009, No. 2, pp. $12-18$

[9] E. V. Evplova Formation of competitive specialist // Secondary professional education, 2008, №6.

[10] L. V. Elagina, V. G. Ryndak As to ensure the formation of professional competence of future specialists // Higher vocational education, 2008, № 6 .

[11] M. S. Emelyanova How to prepare a competitive graduate // Secondary professional education, 2008, №6.

[12] F. S. Ismagilova Managing competitiveness in an environment of innovation // Secondary professional education, 2009, №3.

[13] O. V. Kirshbaum, Increase of competitiveness of graduates on the labour market: institutional aspect: dis. kand. Ekon. sciences'. Omsk, 2007. $218 \mathrm{p}$.

[14] O. M. Kiriluk Formation of the competitive graduate // rector of the University, 2008, № 1.

[15] L. V. L'vov Professional education: competence-context approach: a tutorial. Chelyabinsk CSAU, 2007. 120 p. 